\title{
Evaluation of the antimicrobial activity of pecan nut [Carya illinoinensis (Wangenh) C. Koch] shell aqueous extract on minimally processed lettuce leaves
}

\author{
Sabrina CAXAMBÚ ${ }^{1}$, Elaine BIONDO ${ }^{1}$, Eliane Maria KOLCHINSKI ${ }^{1}$, Rosiele Lappe PADILHA ${ }^{1}$, \\ Adriano BRANDELLI ${ }^{2}$, Voltaire SANT'ANNA ${ }^{1 *}$
}

\begin{abstract}
Pecan nutshell is a residue from food industry that has potential to be used as biopreservative in foods. The objective of this study was to evaluate the antimicrobial activity of pecan nutshell aqueous extract in vitro and its effectiveness to inhibit spoilage microorganisms on lettuce leaves. The results indicate that the aqueous extract presents inhibitory activity against important foodborne pathogenic bacteria such as Listeria monocytogenes, Salmonella Enteritidis, Staphylococcus aureus, Bacillus cereus, Aeromonas hydrophila and Pseudomonas aeruginosa. Antimicrobial activity was not observed against Corynebacterium fimi, Clostridium perfringens, Escherichia coli, and the phytopathogenic fungi tested. When applied onto lettuce leaves, pecan nutshell extract reduced the counts of mesophilic and psychrotrophic bacteria in 2 and $4 \log \mathrm{CFU} / \mathrm{g}$, respectively, during storage of leafy for 5 days at refrigeration temperature $\left(5^{\circ} \mathrm{C}\right)$. The extract was not effective to inhibit yeast on lettuce leaves. Thus, the aqueous extract of pecan shell showed great potential to be used as a natural preservative in foods, acting mainly in the inhibition of spoilage and pathogenic bacteria.
\end{abstract}

Keywords: pecan nutshell; antimicrobial activity; lettuce.

Practical Application: Pecan nutshell aqueous extract has antibacterial activity against pathogenic and spoilage bacteria, being affective to inhibit bacterial growth onto lettuce leaves. Thus, pecan nutshell presents great potential to be used as a natural preservative in foods.

\section{Introduction}

The increased demand for minimally processed foods, with extended shelf life and without addition of chemical preservatives has led industries and research groups to search and develop natural alternatives. Agro-industrial byproduct extracts have shown up as trend because they may represent a natural source of bioactive and biopreservatives compounds (Ayala-Zavala et al., 2011; Siqueira et al., 2013; Gyawali \& Ibrahim, 2014; Andrade et al., 2015), representing a way of industrial waste management, also potentially reflecting on final product costs, due to their potential as low-cost source (Silveira et al., 2013).

Pecan nut [Carya illinoinensis (Wangenh) C. Koch], widely produced in southern Brazil, presents approximately $45 \%$ of its mass as shell, which is an industrial processing residue. Pecan nutshell is a phenolic rich agro-industrial byproduct, which polyphenolic profile includes high concentration of gallic acid, chlorogenic acid, $p$-hydroxybenzoic acid, epigallocatechin and epicatechin gallate (Prado et al., 2014). Due to the elevated concentration of polyphenols, the consumption of its infusion is associated with antioxidant activity, decreasing liver damage, reduction of total cholesterol and action as natural anxiolytic (Malik et al., 2009; Prado et al., 2014; Reckziegel et al., 2011, Müller et al., 2013). Additionally to the benefits to human health, Prado et al. (2014) found that pecan nutshell infusion presents antibacterial activity against Gram-positive bacteria such as Listeria monocytogenes, Staphylococcus aureus, Bacillus cereus, Vibrio parahaemolyticus. On the other hand, authors did not observed inhibition when pecan nutshell infusion was tested against Gram-negative bacteria such as Escherichia coli, Pseudomonas aeruginosa, Salmonella enterica, and fungi such as Aspergillus niger, Aspergillus flavus, Fusarium sp. Rhizopus sp., Penicilium roquefortii (Prado et al., 2014).

In addition to in vitro antimicrobial analysis, it is essential to evaluate the effectiveness of natural agents on real foods. Minimally processed fruits and vegetables are suitable to spoilage and pathogenic bacteria, indicating the need to improve the sanitary conditions along the food chain (Santos et al., 2010; Maistro et al., 2012; Jamali et al., 2013). Since microorganisms may present different sensibility to preservatives, there is still much to be explored and it is essential to maintain efforts to study plant matrixes as source of natural preservatives. In this sense, the evaluation of the antimicrobial activity of aqueous extract of pecan nutshell against a broad range of pathogenic bacteria and fungi and test its effectiveness to inhibit spoilage microorganisms when applied on foods is an important step to suggest their use in large scale. Thus, the objective of the present study was to evaluate the antimicrobial activity of an aqueous extract of pecan shell and its capability to inhibit spoilage fungi and bacteria when applied onto lettuce leaves.

${ }^{1}$ Food Residue Processing Laboratory, Life and Environmental Area, Universidade Estadual do Rio Grande do Sul - UERGS, Campus Encantado, Encantado, RS, Brazil ${ }^{2}$ Applied Biochemistry and Microbiology Laboratory, Food Science and Technology Institute, Universidade Federal do Rio Grande do Sul - UFRGS, Porto Alegre, RS, Brazil 


\section{Materials and methods}

\subsection{Plant material and obtainment of the aqueous extract}

Milled pecan nutshell, from nuts harvest in 2014, was kindly supplied by Agroindústria Pitol (Anta Gorda, RS, Brazil). The material was sieved to $5 \mathrm{~mm}$ particle size and stored at $-18{ }^{\circ} \mathrm{C}$, protected from light, until use. Aqueous extract was prepared by maintaining $10 \mathrm{~g}$ of pecan nutshell with $1 \mathrm{~L}$ of boiling distilled water for $30 \mathrm{~min}$, and then filtered through Whatman filter paper $\mathrm{n}^{\circ} 1$.

\subsection{Antimicrobial activity}

Evaluation of antifungal activity was conducted as described by Venturoso et al. (2011). Sporulated cultures of Bipolaris oryzae, Bipolaris curvispora, Bipolaris cynodontis, Colletotrichum gloeosporioides, Aspergillus phoenicis, Aspergillus flavus, Fusarium oxysporum, Fusarium graminearum, Monascus purpureus were transferred into sodium chloride solution $0.85 \%(\mathrm{w} / \mathrm{v})$, standardized at $10^{4}$ spores per $\mathrm{mL}$ and added to semisolid Potato Dextrose Agar (PDA). Aliquots of $20 \mu \mathrm{L}$ of the pecan nutshell extract were added onto the PDA and plates were incubated at $30^{\circ} \mathrm{C}$ for up to 7 days for evaluation of inhibition zones around the extract drop.

Antibacterial activity was evaluated as described by Kimura et al. (1998). Suspensions of $10^{7} \mathrm{CFU} \mathrm{mL} \mathrm{mL}^{-1}$ of Staphylococcus aureus ATCC25923, Bacillus cereus ATCC14579, Clostridium perfringens ATCC3624, Listeria monocytogenes ATCC7644, Listeria innocua, Pseudomonas aeruginosa ATCC15442, Salmonella Enteritidis ATCC13076, Escherichia coli ATCC25922, Aeromonas hydrophila ATCC7966, Corynebacterium fimi NCTC7547 were spread onto Plate Count Agar (PCA) with a sterile swab and aliquots of $20 \mu \mathrm{L}$ of the extract were applied. Plates were incubated at $37^{\circ} \mathrm{C}$ for $24 \mathrm{~h}$, when the presence of inhibition halos were verified.

\subsection{Antimicrobial activity on lettuce leaves}

To evaluate the antimicrobial activity in minimally processed food, lettuce leaves of $25 \mathrm{~cm}^{2}$ were aseptically prepared, added of pecan nutshell extract at a ratio of $1 \mathrm{~mL}$ per gram of leave and left to dry for $30 \mathrm{~min}$ in laminar flow chamber. Samples were stored in sterile polyethylene bags and left for 5 days at $5{ }^{\circ} \mathrm{C}$. Microbiological analysis was performed at pre-determined times by homogenization of $10 \mathrm{~g}$ samples with $90 \mathrm{~mL}$ of $0.1 \%(\mathrm{w} / \mathrm{v})$ peptone water and further decimal dilutions. Viable spoilage microorganism cells were determined as described by Motta \& Brandelli (2002), incubating mesophilic bacteria on Plate Count Agar (PCA) at $37^{\circ} \mathrm{C}$ for $24 \mathrm{~h}$ and psychrotrophic bacteria on PCA at $7{ }^{\circ} \mathrm{C}$ for up to 10 days. Yeasts were evaluated in PDA by incubation at $30^{\circ} \mathrm{C}$ for 5 days. Results were expressed as Colony Forming Unit per gram of lettuce leaves (CFU g-1).

\subsection{Statistical analysis}

All experiments were conducted in triplicate and averages of two independent tests were calculated. Values were compared by Tukey's test using the software Statistica 10.0 (StatSoft, Tulsa, OK, USA), and differences were considered statistically significant when $p<0.05$. Graphical plots were performed using Microsoft Excel 2000 (MapInfo Corporation, Troy, NY, USA).

\section{Results and discussion}

The results for the evaluation of antibacterial activity of pecan nutshell aqueous extract are shown in Table 1. The extract showed inhibition against $S$. aureus, B. cereus, L. monocytogenes and L. inoccua, although no antimicrobial activity was not observed against $C$. fimi and $C$. perfringens. Similar results were observed by Prado et al. (2014), which verified antimicrobial activity of pecan nutshell infusion against L. monocytogenes, S. aureus, B. cereus and V. parahaemolyticus, important Gram-positive foodborne pathogenic bacteria. However, those authors did not observe antimicrobial activity against the Gram-negative bacteria tested: P. aeruginosa, S. enterica and E. coli (Prado et al., 2014). In the present work, aqueous extract was effective to inhibit Gram-negative bacteria such as $S$. Enteritidis, A. hydrophila and $P$. aeruginosa, although no inhibition was observed against E. coli. Variations in the spectrum of antimicrobial activity may be related to the origin of pecan nutshell and extraction time, which could imply in different composition of the extracts.

Plant extracts possess higher antimicrobial activity compared to pure polyphenols (Puupponen-Pimiä et al., 2001; Prado et al., 2014), suggesting that extracts may exert their action on bacteria due to a combination of different mechanisms. It has been reported that pure polyphenols present antimicrobial activity against Gram-positive and Gram-negative bacteria (Puupponen-Pimiä et al., 2001; Serrano et al., 2009; Prado et al., 2014). Their mechanisms of action are related to oxidation of microbial cell membranes, complexation of essential metal ions, or inhibition of extracellular enzymes (Scalbert, 1991; Serrano et al., 2009). Lou et al. (2012) reported that $p$-coumaric acid acts on altering the permeability of the cell membrane of Gran-negative bacteria. Borges et al. (2013) observed that gallic and ferulic acids are electrophilic products and seem to significantly interact with the bacterial surface component, destabilizing cell cytoplasmic membrane of pathogenic bacteria such as E. coli, L. monocytogenes, $P$. aeruginosa and $S$. aureus. Additionally, antibacterial activity of $p$-coumaric acid is related to the polyphenol capacity to bind DNA inhibiting cell function.

Table 1. Antibacterial activity of pecan nutshell aqueous extract against Gram-positive and Gram-negative bacteria.

\begin{tabular}{lc}
\hline Indicator microorganism & Inhibitory activity \\
\hline Gram-positive & + \\
Staphylococcus aureus & - \\
Corynebacterium fimi & ++ \\
Bacillus cereus & ++ \\
Listeria monocytogenes & ++ \\
Listeria innocua & - \\
Clostridium perfringens & \\
Gram-negative & - \\
Escherichia coli & + \\
Salmonella Enteritidis & + \\
Pseudomonas aeruginosa & + \\
Aeromonas hydrophila & ++ \\
*Averagdiamet of inhibition zon: $+7-10 \mathrm{~mm}++11-15 \mathrm{~mm} ;-$,
\end{tabular}


The analysis of pecan nutshell extract against phytopathogenic fungi showed no capability to inhibit $B$. oryzae, B. curvispora, B. cynodontis, C. gloeosporioides, A. phoenicis, A. flavus, F. oxysporum, F. graminearum or M. purpureus. Prado et al. (2014) also verified that pecan nutshell infusion was not effective to inhibit A. niger, A. flavus, P. roquefortii, Rhizopus sp. and Fusarium sp. The absence of inhibitory activity against fungi may be related to a low concentration of compounds with antifungal activity due to the extraction methodology. Additionally, some fungi such as A. niger and Penicillium sp. can grow in the presence of tannins, using these compounds as a carbon source or due to production of polyphenol hydrolyzing enzymes (Scalbert, 1991; Serrano et al., 2009).

Figure 1 shows the results for antimicrobial activity of pecan nutshell extract against yeast, mesophilic and psychrotrophic bacteria in lettuce leaves stored for 5 days at refrigeration temperature. The control experiment showed that the concentration of mesophilic bacteria (Figure 1A) in lettuce leaves remained constant over the 5 days of storage with viable counts around $6 \log \mathrm{CFU} / \mathrm{g}(\mathrm{p}>0.05)$. When the pecan extract was used, mesophilic bacterial counts was significantly reduced $(p<0.05)$ $3.5 \log \mathrm{CFU} / \mathrm{g}$ when samples were stored for 5 days. The analysis of psychrotrophic bacteria (Figure 1B) in the control experiment indicates that the microbial counts increased significantly $(p<0.05)$ during the storage of the lettuce leaves from $4.9 \mathrm{log}$ $\mathrm{CFU} / \mathrm{g}$ on day zero to $6.3 \log \mathrm{CFU} / \mathrm{g}$ on the fifth day of storage. The application of the pecan nutshell extract on the samples implied on significant reduction $(p<0.05)$ of psychrotrophic bacteria counts to $2.1 \log \mathrm{CFU} / \mathrm{g}$ on the third day of storage, which remained constant up to the fifth day of storage ( $p>0.05$ ). Similar to results observed on in vitro antifungal tests, pecan nutshell extract did not inhibit significantly $(p>0.05)$ the yeast growth on lettuce leaves during the storage time (Figure 1C).

The results of the present work indicate that pecan nutshell extract may support an increased shelf life to lettuce leaves, since mesophilic and psychrotrophic bacteria are directly related to spoilage of foods.

\section{Conclusion}

The results of the present study show that pecan nutshell extract has antibacterial activity against important pathogenic bacteria, but does not show inhibitory activity against the tested fungi. When applied onto lettuce leaves, the extract was effective in reducing the counts of mesophilic and psychrotrophic bacteria over 5 days of storage of the product at refrigeration temperature. Thus, the results indicate that pecan nutshell extract offers an interesting potential to be used as a natural antimicrobial for food applications.

\section{Acknowledgements}

This project has received support from State University of Rio Grande do Sul (UERGS, Brazil). S. Caxambú received a fellowship from Fundação de Amparo à Pesquisa do Rio Grande do Sul (FAPERGS, Brazil). Authors thank Dr. Evelise Bach for technical support.
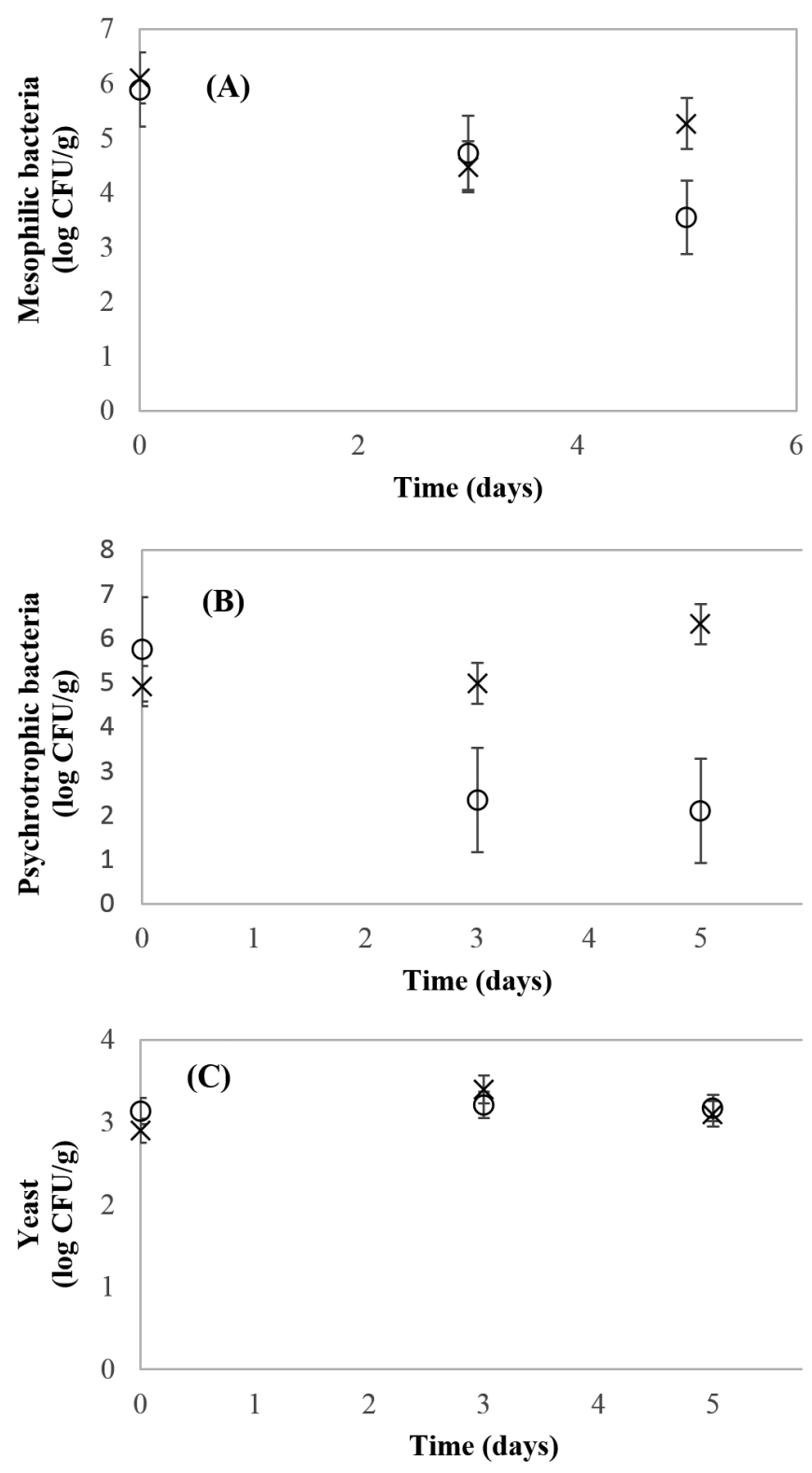

Figure 1. Mesophilic (A), psychrotrophic (B) and yeast (C) counts on lettuce leaves treated with water $(\mathrm{x})$ or pecan nutshell aqueous extract (o) during 5 days of storage at refrigeration temperature.

\section{References}

Andrade, R. A. M. S., Maciel, M. I. S., Santos, A. M. P., \& Melo, E. A. (2015). Optimization of the extraction of polyphenols from cashew apple agro-industrial residues. Food Science and Technology, 35(2), 354-360

Ayala-Zavala, J. F., Vega-Vega, V., Rosas-Domínguez, C., Palafox-Carlos, H., Villa-Rodriguez, J. A., Siddiqui, M. W., Dávila-Aviña, J. E., \& González-Aguilar, G. A. (2011). Agro-industrial potential of exotic fruit byproducts as a source of food additives. Food Research International, 44(7), 1866-1874. http://dx.doi.org/10.1016/j.foodres.2011.02.021.

Borges, A., Ferreira, C., Saavedra, M. J., \& Simões, M. (2013). Antibacterial activity and mode of action of ferulic and gallic acids against pathogenic bacteria. Microbial Drug Resistance, 19(4), 256-265. http://dx.doi. org/10.1089/mdr.2012.0244. PMid:23480526. 
Gyawali, R., \& Ibrahim, S. A. (2014). Natural products as antimicrobial agents. Food Control, 46, 412-429. http://dx.doi.org/10.1016/j. foodcont.2014.05.047.

Jamali, H., Chai, L. C., \& Thong, K. L. (2013). Detection and isolation of Listeria spp. and Listeria monocytogenes in ready-to-eat foods with various selective culture media. Food Control, 32(1), 19-24. http://dx.doi.org/10.1016/j.foodcont.2012.11.033.

Kimura, H., Sashihara, T., Matsusaki, H., Sonomoto, K., \& Ishizaki, I. (1998). Novel bacteriocin of Pediococcus sp. ISK-1 isolated from wellaged bed of fermented rice bran. Annals of the New York Academy of Sciences, 864(1), 345-348. http://dx.doi.org/10.1111/j.1749-6632.1998. tb10336.x. PMid:9928112.

Lou, Z., Wang, H., Rao, S., Sun, J., Ma, C., \& Li, J. (2012). p-Coumaric acid kills bacteria through dual damage mechanisms. Food Control, 25(2), 550-554. http://dx.doi.org/10.1016/j.foodcont.2011.11.022.

Maistro, L. C., Miya, N. T. N., Sant'Ana, A. S., \& Pereira, J. L. (2012). Microbiological quality and safety of minimally processed vegetables marketed in Campinas, SP - Brazil, as assessed by traditional and alternative methods. Food Control, 28(2), 258-264. http://dx.doi. org/10.1016/j.foodcont.2012.05.021.

Malik, N. S. A., Perez, J. L., Lombardini, L., Cornacchia, R., CisnerosZevallos, L., \& Braford, J. (2009). Phenolic compounds and fatty acid composition of organic and conventional grown pecan kernel. Journal of the Science of Food and Agriculture, 89(13), 2207-2213. http://dx.doi.org/10.1002/jsfa.3708.

Motta, A. S., \& Brandelli, A. (2002). Characterization of an antimicrobial peptide produced by Brevibacterium linens. Journal of Applied Microbiology, 92(1), 63-70. http://dx.doi.org/10.1046/j.13652672.2002.01490.x. PMid:11849329.

Müller, L. G., Pase, C. S., Reckziegel, P., Barcelos, R. C., Boufleur, N., Prado, A. C., Fett, R., Block, J. M., Pavanato, M. A., Bauermann, L. F., da Rocha, J. B., \& Burger, M. E. (2013). Hepatoprotective effects of pecan nut shells on ethanol-induced liver damage. Experimental and Toxicologic Pathology, 65(1-2), 165-171. http://dx.doi.org/10.1016/j. etp.2011.08.002. PMid:21924598.

Prado, A. C. P., Silva, H. S., Silveira, S. M., Barreto, P. L. M., Vieira, C. R. W., Maraschin, M., Ferreira, S. R. S., \& Block, J. M. (2014). Effect of the extraction process on the phenolic compounds profile and the antioxidant and antimicrobial activity of extracts of pecan nut
[Carya illinoinensis (Wangenh) C. Koch] shell. Industrial Crops and Products, 52, 552-561. http://dx.doi.org/10.1016/j.indcrop.2013.11.031.

Puupponen-Pimiä, R., Nohynek, L., Meier, C., Kähkönen, M., Heinonen, M., Hopia, A., \& Oksman-Caldentey, K. M. (2001). Antimicrobial properties of phenolic compounds from berries. Journal of Applied Microbiology, 90(4), 494-507. http://dx.doi.org/10.1046/j.13652672.2001.01271.x. PMid:11309059.

Reckziegel, P., Boufleur, N., Barcelos, R. C. S., Benvegnú, D. M., Pase, C. S., Müller, L. G., Teixeira, A. M., Zanella, R., Prado, A. C. P., Fett, R., Block, J. M., \& Burger, M. E. (2011). Oxidative stress and anxiety-like symptoms related to withdrawal of passive cigarette smoke in mice: beneficial effects of pecan nut shells extract, a byproduct of the nut industry. Ecotoxicology and Environmental Safety, 74(6), 1770-1778. http://dx.doi.org/10.1016/j.ecoenv.2011.04.022. PMid:21531023.

Santos, T. B. A., Silva, N., Junqueira, V. C. A., \& Pereira, J. L. (2010). Microrganismos indicadores em frutas e hortaliças minimamente processadas. Brazilian Journal of Food Technology, 13(2), 141-146. http://dx.doi.org/10.4260/BJFT2010130200019.

Scalbert, A. (1991). Antimicrobial properties of tannins. Phytochemistry, 30(12), 3875-3883. http://dx.doi.org/10.1016/0031-9422(91)83426-L.

Serrano, J., Puupponen-Pimiã, R., Dauer, A., Aura, A.-M., \& SauraCalixto, F. (2009). Tannins: current knowledge of food sources, intake, bioavailability and biological effects. Molecular Nutrition \& Food Research, 53(Suppl 2), 310-329. http://dx.doi.org/10.1002/ mnfr.200900039. PMid:19437486.

Silveira, S. T., Daroit, D. J., Sant'Anna, V., \& Brandelli, A. (2013). Stability modeling of red pigments produced by Monascus purpureus in submerged cultivations with sugar cane. Food and Bioprocess Technology, 6(4), 1007-1014. http://dx.doi.org/10.1007/s11947011-0710-8.

Siqueira, B. S., Soares, M. S. S. Jr., Fernandes, K. F., Caliari, M., \& Damiani, C. (2013). Effect of soaking on the nutritional quality of pequi (Caryocar brasiliense Camb.) peel flour. Food Science and Technology, 33(3), 500-506. http://dx.doi.org/10.1590/S010120612013005000081.

Venturoso, L. R., Bacchi, L. M. A., Gavassoni, W. L., Conus, L. A., Pontim, B. C. A., \& Bergamin, A. C. (2011). Atividade antifúngica de extratos vegetais sobre o desenvolvimento de fitopatógenos. Summa Phytopathologica, 37(1), 18-23. http://dx.doi.org/10.1590/ S0100-54052011000100003. 